\title{
Generation and Therapeutic Efficacy of Highly Oligomer-Specific $\beta$-Amyloid Antibodies
}

\author{
Heinz Hillen, ${ }^{1 *}$ Stefan Barghorn, ${ }^{1}$ Andreas Striebinger, ${ }^{1}$ Boris Labkovsky, ${ }^{2}$ Reinhold Müller, ${ }^{1}$ Volker Nimmrich, ${ }^{1}$ \\ Marc W. Nolte, ${ }^{1}$ Claudia Perez-Cruz, ${ }^{1}$ Ingrid van der Auwera, ${ }^{3}$ Fred van Leuven, ${ }^{4}$ Marcel van Gaalen, ${ }^{1}$ \\ Anton Y. Bespalov, ${ }^{1}$ Hans Schoemaker, ${ }^{1}$ James P. Sullivan, ${ }^{5}$ and Ulrich Ebert ${ }^{1 \star}$ \\ ${ }^{1}$ Neuroscience Research, Global Pharmaceutical Research and Development, Abbott, D-67061 Ludwigshafen, Germany, ${ }^{2}$ Abbott BioResearch Center, \\ Worcester, Massachusetts 01605, ${ }^{3}$ reMYND NV, BE-3001 Leuven, Belgium, ${ }^{4}$ Experimental Genetics Group, Katholieke Universiteit Leuven, BE-3000 \\ Leuven, Belgium, and ${ }^{5}$ Neuroscience Research, Global Pharmaceutical Research and Development, Abbott, Abbott Park, Illinois 60064
}

Oligomers of the $\beta$-amyloid $(\mathrm{A} \beta)$ peptide have been indicated in early neuropathologic changes in Alzheimer's disease. Here, we present a synthetic $\mathrm{A} \beta_{20-42}$ oligomer (named globulomer) with a different conformation to monomeric and fibrillar $\mathrm{A} \beta$ peptide, enabling the generation of highly $\mathrm{A} \beta$ oligomer-specific monoclonal antibodies. The globulomer-derived antibodies specifically detect oligomeric but not monomeric or fibrillar $\mathrm{A} \beta$ in various $\mathrm{A} \beta$ preparations. The globulomer-specific antibody $\mathrm{A}-887755$ was able to prevent $\mathrm{A} \beta$ oligomer binding and dynamin cleavage in primary hippocampal neurons and to reverse globulomer-induced reduced synaptic transmission. In amyloid precursor protein (APP) transgenic mice, vaccination with $\mathrm{A} \beta$ globulomer and treatment with $\mathrm{A}-887755$ improved novel object recognition. The cognitive improvement is likely attributable to reversing a deficit in hippocampal synaptic spine density in APP transgenic mice as observed after treatment with A-887755. Our findings demonstrate that selective reduction of A $\beta$ oligomers by immunotherapy is sufficient to normalize cognitive behavior and synaptic deficits in APP transgenic mice.

\section{Introduction}

Although being an abundant peptide with a high turnover rate (Bateman et al., 2006), $\beta$-amyloid (A $\beta$ ) is considered a critical contributor to the generation and progression of Alzheimer's disease $(\mathrm{AD}) . \mathrm{A} \beta$ is a major component of amyloid plaque deposits in the brain, one of the defining pathological hallmarks of this type of dementia (Hardy and Selkoe, 2002). Although production and metabolism of high amounts of $A \beta$ are associated with normal brain function, several hypotheses have been developed how this peptide may become pathogenic for neurons and brain function.

Based on the high prevalence of the 42 -aa-long version of $\mathrm{A} \beta$ in amyloid plaques, the amyloid cascade hypothesis of Hardy and Higgins (1992) suggested that an overproduction of the more hydrophobic $\mathrm{A} \beta_{1-42}$ compared with the more abundant $\mathrm{A} \beta_{1-40}$ triggers aggregation of $\mathrm{A} \beta$ into fibrils and plaques, which initiates AD pathology. However, this hypothesis is not able to explain an obvious discrepancy between amyloid plaque load and degree of dementia in AD (Katzman et al., 1988). In 1999, several groups reported a much better correlation of the soluble $\mathrm{A} \beta$ fraction in

\footnotetext{
Received Nov. 18, 2009; revised May 28, 2010; accepted June 12, 2010.

We are grateful to our colleagues from Abbott, in particular Gerry Fox, Gerhard Gross, and Alfred Hahn for helpful discussion, Nathan Rustay for providing Tg2576 mouse brains, and Bodo Janson and Tanja Georgi for excellent technical support. We thank Manuela Neumann (Brain-Net, Munich, Germany) for providing the AD and control brain samples.

${ }^{*}$ H.H. and U.E. contributed equally to this work as senior authors.

The salaries of authors (except for I.v.d.A. and F.v.L.) and the study were funded as part of an ongoing drug discovery program at Abbott Laboratories.

Correspondence should be addressed to Ulrich Ebert or Heinz Hillen, Neuroscience Research, Knollstrasse, D-67061 Ludwigshafen, Germany, E-mail: ulich.ebert@abbott.com or heinz.hillen@abbott.com.

DOI:10.1523/JNEUROSCI.5721-09.2010

Copyright $\odot 2010$ the authors $\quad 0270-6474 / 10 / 3010369-11 \$ 15.00 / 0$
}

postmortem AD brain extracts with disease symptoms (Lue et al., 1999; McLean et al., 1999; Wang et al., 1999). These finding supported data that connected the pathological nature of $A \beta$ to its oligomeric state (Lambert et al., 1998). Thus, A $\beta$ oligomers became the focus of $\mathrm{AD}$ research and have subsequently been generated synthetically (Barghorn et al., 2005), harvested from medium after release by amyloid precursor protein (APP)transfected $\mathrm{CHO}$ cell cultures (Walsh et al., 2002), or isolated from the brain of APP transgenic mice (Lesné et al., 2006). These preparations were useful to demonstrate $\mathrm{A} \beta$ oligomer pathology in animal models (Walsh et al., 2002; Lesné et al., 2006) and indicated in primary hippocampal neuronal culture that their major pathogenic mechanisms in $\mathrm{AD}$ pathology is impairment of synaptic activity (Lacor et al., 2007; Shankar et al., 2007). However, molecular characteristics of the pathological $A \beta$ oligomers are still not fully elucidated, mainly because the preparations are either containing different $\mathrm{A} \beta$ species with undefined stability [e.g., so-called amyloid-derived diffusible ligands (ADDLs)] (Lambert et al., 1998) or because they were resistant to purification when extracted from biological sources (Walsh et al., 2002; Lesné et al., 2006). Thus, it remains under discussion whether the pathology of $A \beta$ oligomers is related to its size, e.g., trimer (Walsh et al., 2002) or dodecamer (Lesné et al., 2006), or to its conformation. Likewise, the available preparations did not allow generation of $\mathrm{A} \beta$ oligomer-selective monoclonal antibodies that do not bind $\mathrm{A} \beta$ monomers and fibrils and thus would have been able to prove that neutralization of $A \beta$ oligomers is sufficient to reduce $\mathrm{AD}$ pathology.

Here, we show that a synthetic $\mathrm{A} \beta$ oligomer preparation can be used to generate monoclonal antibodies that selectively detect 
$\mathrm{A} \beta$ oligomers in APP transgenic mouse and AD brain tissue. Importantly, this type of antibody is able to prevent pathological effects of $\mathrm{A} \beta$ oligomers in vitro and in vivo, indicating that neutralization of $A \beta$ oligomers by specific antibodies is sufficient for efficacy in a preclinical AD model and should be therefore tested for therapeutic efficacy in $\mathrm{AD}$.

\section{Materials and Methods}

$A \beta_{20-42}$ globulomer and antibody generation. The $\mathrm{A} \beta_{20-42}$ globulomer was generated from the $A \beta_{1-42}$ globulomer by limited proteolysis with thermolysine (1:50). This synthetic $\mathrm{A} \beta$ oligomer proved extremely resistant to physical and chemical treatment over time (for details, see Barghorn et al., 2005). Monoclonal antibodies were generated from mice immunized with $\mathrm{A} \beta_{20-42}$ globulomer according to standard procedures and tested for their selectivity to $\mathrm{A} \beta_{20-42}$ globulomer versus other $\mathrm{A} \beta$ conformers using a standard dot blot assay.

Biacore analysis. The $\mathrm{A} \beta_{20-42}$ globulomer antigen was immobilized on Biacore sensor chips CM5, and $k_{\text {on }}$ and $k_{\text {off }}$ for A-887755 binding was determined according to standard techniques.

Surface-enhanced laser desorption/ionization-mass spectrometry analysis. A $\beta$ peptide mass was determined by surface-enhanced laser desorption/ionization-mass spectrometry (SELDI-MS) using $\mathrm{H} 4$ protein chips (Bio-Rad) and $\alpha$-cyano-4-hydroxy-cinnamic acid in 50\% acetonitril/ $0.5 \%$ trifluor acetic acid as matrix.

Tissue extracts. A $\beta$ peptides were extracted from brain samples using two different buffer conditions. Clinically characterized human brain neocortical samples (supplemental Table 1, available at www.jneurosci. org as supplemental material) were homogenized in either 3\% SDS extraction buffer $[0.1 \mathrm{~g} / \mathrm{ml}$ in $50 \mathrm{~mm}$ Tris, $150 \mathrm{~mm} \mathrm{NaCl}, 0.5 \%$ Triton X-100, 1 mm EGTA, 3\% SDS, and 1\% Na-desoxycholate, pH 7.4, with complete protease inhibitor cocktail (Roche Diagnostics) and $1 \mathrm{~mm}$ PMSF] or PBS extraction buffer $\left(0.1 \mathrm{~g} / \mathrm{ml}\right.$ in $20 \mathrm{~mm} \mathrm{NaH}_{2} \mathrm{PO}_{4}$, and 140 $\mathrm{mm} \mathrm{NaCl}, \mathrm{pH}$ 7.4, with complete protease inhibitor cocktail and $1 \mathrm{~mm}$ PMSF) with $\sim 20$ strokes in a glass potter and followed by an ultra turrax homogenizer for $30 \mathrm{~s}$. The $3 \%$ SDS samples were incubated for $30 \mathrm{~min}$ at room temperature and centrifuged for $10 \mathrm{~min}$ at $16,000 \times g$ at $20^{\circ} \mathrm{C}$. The PBS samples were incubated for $30 \mathrm{~min}$ on ice and centrifuged for $30 \mathrm{~min}$ at $16,000 \times g$ at $20^{\circ} \mathrm{C}$, and the supernatants were analyzed for $\mathrm{A} \beta$ peptides using quantitative immunoprecipitation. Extraction of $A \beta$ peptides from Tg2576 mice (Taconic Farms) brain (3\% SDS only) followed the same protocol. Clinically characterized human plasma and CSF samples (supplemental Tables 2, 3, available at www.jneurosci.org as supplemental material) were also used for immunoprecipitation.

Immunoprecipitation. For immunoprecipitation, mouse anti- $\mathrm{A} \beta$ antibodies were coupled to anti-mouse antibody magnetic beads (Dynabeads). The samples were incubated with the magnetic beads overnight at $4^{\circ} \mathrm{C}$, washed three times with PBS, eluted with $50 \%$ acetonitrile/ $0.5 \%$ trifluoroacetic acid, and subjected to standard quantitative Western blot.

Cell culture and $A \beta$ binding assay. Hippocampal rat brain neurons (embryonic day 18 ) were cultured for $\sim 21 \mathrm{~d}$ in vitro in 24 -well plates on poly-D-lysine-coated coverslips in Neurobasal medium with B27 supplement at $37^{\circ} \mathrm{C}, 5 \% \mathrm{CO}_{2}$. For antibody-mediated $\mathrm{A} \beta$ globulomer binding inhibition, $8.3 \mathrm{~nm} \mathrm{~A} \beta_{20-42}$ globulomer (calculated from the initial $100 \mathrm{~nm}$ $\mathrm{A} \beta$ monomer) was incubated for $1 \mathrm{~h}$ at $37^{\circ} \mathrm{C}$ with $16.7 \mathrm{~nm} \mathrm{~A}-887755$ or a non-A $\beta$-binding isotype control antibody [IgG2a, directed against key limpet hemocyanine (Abbott Bioresearch Center)] and subsequently applied for $15 \mathrm{~min}$ at $37^{\circ} \mathrm{C}$ to the hippocampal neurons. After intensive washing, cells were fixed and stained with immunofluorescence-labeled antibodies to $\mathrm{A} \beta$ globulomer and the neuron-specific marker MAP2 and with DAPI ( $4^{\prime}, 6^{\prime}$-diamidino-2-phenylindole) for cell-body localization.

$A \beta$-induced dynamin cleavage. $\mathrm{A} \beta$ was aggregated according to the literature (Kelly et al., 2005; Kelly and Ferreira, 2006) with slight modifications. Briefly, $\mathrm{A} \beta_{1-40}$ (American Peptide) was dissolved in serum-free culture medium at $0.1 \mathrm{mg} / \mathrm{ml}$ and incubated at $37^{\circ} \mathrm{C}$ for $4 \mathrm{~d}$. Anti-A $\beta$ globulomer antibody A-887755, the non-A $\beta$-binding IgG2a isotype control antibody, or PBS was incubated with the aggregated $\mathrm{A} \beta$ at $25^{\circ} \mathrm{C}$ for $1 \mathrm{~h}$ under constant agitation in a final volume of $0.225-1 \mathrm{ml}$. The mixtures were added to the culture medium resulting in a final concentration of $5 \mu \mathrm{M} \mathrm{A} \beta$ (calculated from initial $\mathrm{A} \beta$ monomer) and $2 \mu \mathrm{M}$ antibody, respectively. Every treatment was performed in triplicate, and wells without addition of $\mathrm{A} \beta$ or antibodies were included as additional controls. Cells were cultivated for another $24 \mathrm{~h}$ and briefly inspected by light microscopy before being processed for Western blot. Treatment with $\mathrm{A} \beta$ did not induce overt neuronal death during the incubation period.

Slice culture experiment. Hippocampal slice cultures were prepared from 9-d-old Wistar rats (Janvier). In brief, $400 \mu \mathrm{m}$ hemisphere slices were prepared using a tissue chopper (Mickle Laboratory Engineering Co. Ltd.) and cultured on Millicell-CM membranes (Millipore Corporation) in high-K medium [ $40 \%$ basal medium Eagle with Earle's salts, 25\% horse serum, 25\% Earle's balanced salt solution, 1 mm Glutamax I, $28 \mathrm{~mm}$ glucose (40\%), and 10\% $250 \mathrm{~mm}$ NaHEPES (Sigma-Aldrich; all other ingredients were from Invitrogen)] at $34^{\circ} \mathrm{C}, 5 \% \mathrm{CO}_{2}$ for $3 \mathrm{~d}$ and then in Neurobasal A medium [96.4\% Neurobasal A medium, 2\% B-27 supplement, $1 \mathrm{~mm}$ L-glutamine (Invitrogen), and $25 \mathrm{~mm} \mathrm{D}$-glucose (SigmaAldrich)]. At $24 \mathrm{~h}$ before recording, $160 \mathrm{~nm} \mathrm{~A} \beta_{20-42}$ globulomer, globulomer plus 100 nм A-887755, or globulomer ultrafiltrate plus 830 nм SDS (vehicle control) was applied to the slice culture medium. Shortly before recording, slice cultures were placed in a Haas-interface recording chamber (Harvard Apparatus) and allowed to equilibrate for at least 60 min at $32^{\circ} \mathrm{C}$. The Schaffer collateral was then stimulated with bipolar pulses ( $0.1 \mathrm{~ms} /$ phase) using a $0.5 \mathrm{M} \Omega$ bipolar Tungsten electrode (WPI), and field EPSP amplitudes were recorded with glass electrodes (0.7-1.1 $\mathrm{M} \Omega$, GC150F-15; Harvard Apparatus). Signals were digitized using a power CED 1401 (Cambridge Electronic Design) and analyzed using Signal 2.14 software (Cambridge Electronic Design).

Immunohistology. Brain material of 19-month-old Tg2576 mice (Taconic Farms) and autopsy material of two Alzheimer's disease patients (RZ16 and RZ55; obtained from BrainNet) was used. The animals were deeply anesthetized and transcardially perfused with $0.1 \mathrm{~m}$ PBS to flush the blood. Then the brain was removed from the cranium and divided longitudinally. One hemisphere of the brain was shock frozen and used for $\mathrm{A} \beta$ oligomer extraction (see above), and the other was fixated by immersion into $4 \%$ paraformaldehyde. The immersion-fixated hemisphere was cryoprotected by soaking in 30\% sucrose in PBS and mounted on a freezing microtome. The entire forebrain was cut into $40 \mu \mathrm{m} \mathrm{sec-}$ tions that were collected in PBS and used for the subsequent staining procedure. The human brain material was an $\sim 1 \mathrm{~cm}^{3}$ deep-frozen block of the neocortex. A small part of the block was immersion fixated in $4 \%$ paraformaldehyde and further treated like the mouse brain material. Antibody staining was performed by incubating the sections with a solution containing $0.07-7.0 \mu \mathrm{g} / \mathrm{ml}$ of the conformation-independent antibodies 6E10 (Signet Labs) and 6G1 (generated by Abbott) (Barghorn et al., 2005) or the globulomer-specific antibody A-887755 in accordance with the following protocol (at room temperature if not indicated otherwise). Floating sections were transferred into ice-cold $0.3 \% \mathrm{H}_{2} \mathrm{O}_{2}$ for $30 \mathrm{~min}$, subsequently washed in Tris-buffered saline with Tween 20 (TBST) $(10 \times$ concentrate; S3306, 1:10 in Aqua bidest; Dako Cytomation), and incubated with 5\% donkey serum/TBST for $20 \mathrm{~min}$. Then, sections were directly transferred to the primary antibody solution and incubated for $24 \mathrm{~h}$. After thorough washing in TBST, nonspecific staining was blocked by blocking serum (Vectastain Elite ABC peroxidase kit) for $20 \mathrm{~min}$, washed again in TBST, and incubated with a biotinylated donkey anti-mouse antibody (1:500 in TBST; Jackson ImmunoResearch) for 60 min. Before and after incubation with StreptABComplex (Dako Cytomation), for $60 \mathrm{~min}$, the sections were washed in TBST. Finally, the sections were stained with diaminobenzidine (Vectastain Elite ABC peroxidase kit) for $20 \mathrm{~min}$, mounted on glass slides, air dried, dehydrated, and coverslipped in xylol-free embedding medium (X-tra kitt; Medite)

Staining was photographed using a Carl Zeiss Axioplan microscope, and amyloid staining was additionally quantified by graphically excising 10 randomly selected plaques from the histological images using the ImagePro 5.0 image analysis system and determining their average grayscale value. Optical density values were calculated from the grayscale values by subtracting the mean background density of the stained material from the density of amyloid plaques $(0 \%$, no plaque staining above surrounding background; 100\%, no transmission/maximal staining). All analysis was performed blinded to the used antibody. 


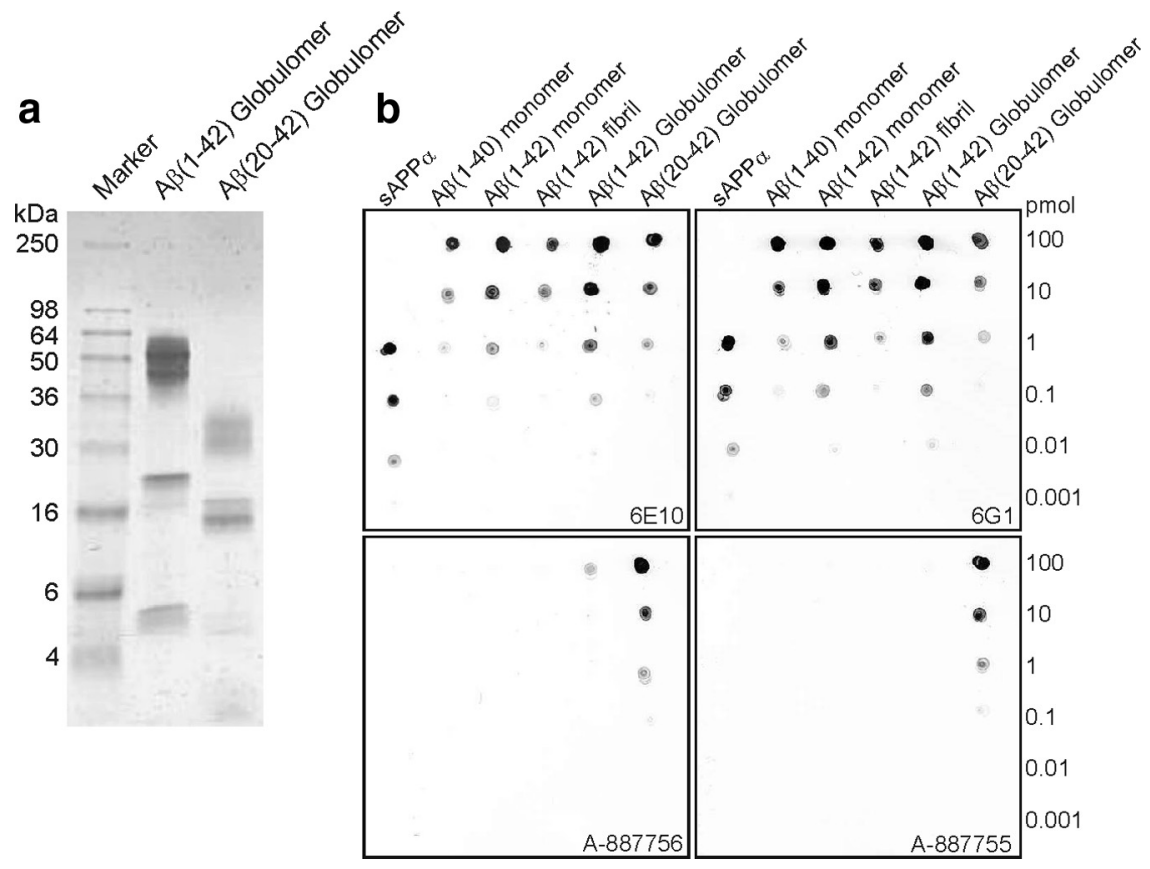

Figure 1. Generation of $A \beta_{20-42}$ globulomer and selective antibodies. $\boldsymbol{a}$, The Coomassie-stained SDS-PAGE shows the characteristic apparent band pattern of $A \beta_{20-42}$ globulomer after limited proteolysis of $A \beta_{1-42}$ globulomer with thermolysine. $\boldsymbol{b}$, Dot blot of decreasing amounts of diverse $A \beta$ conformers demonstrate the selectivity of mouse monoclonal anti-A $\beta$ globulomer antibodies. Top row, Immunization of mice with $A \beta_{1-42}$ globulomer generated $6 \mathrm{G1}$-type antibodies that are $A \beta$ conformer nonspecific and comparable with the commercially available $A \beta$ conformer nonspecific $6 E 10$ antibody. Bottom row, $A \beta_{20-42}$ globulomerimmunized mice generated highly selective antibodies recognizing $A \beta_{1-42}$ and $A \beta_{20-42}$ globulomer ( $A-887756$ ) or $A \beta_{20-42}$ globulomer only (A-887755).

For analysis of tissue cross-reactivity, FITC-labeled A-887755 was prepared and incubated at 0.1 and $10 \mu \mathrm{g} / \mathrm{ml}$ with standard tissues of cynomolgus monkey and man (Charles River).

Behavioral experiments. For the cognition testing, male and female APP transgenic mice carrying the London mutation (APP/L) (Moechars et al., 1999) and age-matched littermate wild-type control mice were bred in-house and were individually housed under standard laboratory conditions with access to food and water ad libitum. Experimental procedures were approved by the Animal Welfare Office of reMYND or Abbott and were performed in accordance with the European and German national guidelines as well as recommendations and policies of the National Institutes of Health Principles of Laboratory Animal Care (1996 edition). All experiments were performed during the light phase of a $12 \mathrm{~h}$ light/dark cycle.

The novel object recognition task was performed in 4.5-month-old mice. For this test, the mice were individually placed and accustomed to an arena and then exposed to two identical elements (blue pyramid, green cube, yellow cylinder of similar size, $\sim 4 \mathrm{~cm}$ ) for $10 \mathrm{~min}$ (acquisition phase). The duration and frequency with which the mouse explored the objects were recorded. During the retention phase, $2.5 \mathrm{~h}$ later, mice were returned to the arena that now contained, in addition to the known object, an unknown object randomly selected from the other objects. Recognition of the new object was recorded as the time during which the mouse was exploring the old object relative to total time (exploration of old and new object), the recognition index. A mouse that does not remember the known object will consider it as equally interesting as the new object and spend an equal amount of time on exploring it (recognition index of 50\%), whereas a mouse that remembers the known object will consider it as not interesting and therefore show a significantly higher recognition index. APP/L mice are known to have memory deficits in this test at 4.5 months of age, i.e., a recognition index of $\sim 50 \%$ (Dewachter et al., 2002)

In a first study (active immunization), 1.5-month-old APP/L mice received $100 \mu \mathrm{g}$ of $\mathrm{A} \beta_{1-42}$ monomer (in $0.1 \% \mathrm{NH}_{4} \mathrm{OH}$ ), $\mathrm{A} \beta_{1-42}$ globulomer, or $\mathrm{A} \beta_{20-42}$ globulomer in PBS mixed with an equal amount of complete Freund's adjuvant intraperitoneally, followed by booster injections with the same amount of antigen in incomplete Freund's adjuvant every third week for 3 months before being subjected to the object recognition task. In a second study (passive immunotherapy), the task was performed in 4- to 5-month-old $\mathrm{APP} / \mathrm{L}$ mice $1 \mathrm{~d}$ after receiving the last of three injections of $500 \mu \mathrm{g}$ of antibody (6G1 or A-887755) or $250 \mu \mathrm{l}$ of saline (vehicle) separated by 1 week.

For the Morris water maze task, a custommade pool (100 cm diameter) with white, nontransparent walls was located in a well-lit room with a number of distal extramaze cues. The daily filled and drained water $\left(25^{\circ} \mathrm{C}\right)$ was made opaque with coffee creamer, and water surface was $\sim 10 \mathrm{~cm}$ from the top of the pool edge. A clear Plexiglas escape platform ( $9 \mathrm{~cm}$ diameter) was located $0.5 \mathrm{~cm}$ below the water surface in the center of one of eight equally sized pool sectors $(\sim 20 \mathrm{~cm}$ from the edge of the platform to the pool wall). The platform location was selected randomly for each mouse but was kept constant for each individual mouse throughout training. For each trial, a mouse was released from any of eight start boxes (filled with water and separated from the pool by the manually operated sliding door) and had $60 \mathrm{~s}$ to locate the escape platform, where it was allowed to remain for $10 \mathrm{~s}$. The mouse was then returned to its holding cage, which was located under an incandescent read heat lamp. If the platform was not found in the allotted time, the mouse was gently placed on the platform using an appropriately sized plastic spoon. The mice were given two trials per day for $5 \mathrm{~d}$, followed by a final training after the weekend. Four mice were trained successively in a group enabling intertrial intervals to be $5 \mathrm{~min}$. The mice were tracked in the pool by a Ethovision video tracking system (Noldus). APP/L mice or transgenic littermates of 5.5 months of age were divided into four groups: transgenic mice treated with PBS or with A-887755 (500 $\mu$ g, i.p.) and wild-type mice treated with PBS or with A-887755. Antibody or PBS were injected on days 1, 6, 11, and 16 of the experiment. Water maze training took place on days $12-16$ and day 19 . Measures of latency to find the platform, path length, and swimming speed were obtained for each trial, and then averaged daily values were subjected to three-way ANOVA with repeated measures on time. Whenever applicable for repeated measures analysis, Mauchly's test of sphericity was applied and the degrees of freedom were corrected to more conservative values using the Huynh-Feldt's $\varepsilon$ for any terms involving factors in which the sphericity assumption was violated.

Spine density quantification. Female Tg2576 mice (5.5 months of age; Taconic Farms) were treated with A-887755 (500 $\mu$ g in PBS, i.p.) or vehicle once weekly for 3 weeks. Then, the mice were deeply anesthetized and perfused with $0.9 \%$ saline $(10 \mathrm{~min})$. The right hemisphere was dissected out and processed for a modified Golgi-Cox staining as described by the manufacturer (Rapid Golgi; FD NeuroTechnologies). Coronal sections $(240 \mu \mathrm{m})$ were obtained using a freezing-sliding microtome, mounted on $2 \%$ gelatin-coated glass slides, and stored in Golgi solution in the dark at room temperature. After 2 weeks, sections were rinsed, dehydrated, and cleared of xylenes, and slides were coverslipped and allowed to dry before quantitative analysis. Several pyramidal neurons impregnated with the Golgi solution were readily identified in the dorsal hippocampal region by their characteristic triangular soma shape and numerous dendritic spines. At least four neurons per animal were threedimensionally reconstructed by NeuroLucida Software (MicroBrightField). For spine quantification, a $100 \times$ oil-immersion objective was used to identify mushroom-like spines in dendrites longer than $10 \mu \mathrm{m}$. Straight branches were preferred to have a clear presentation of 
a

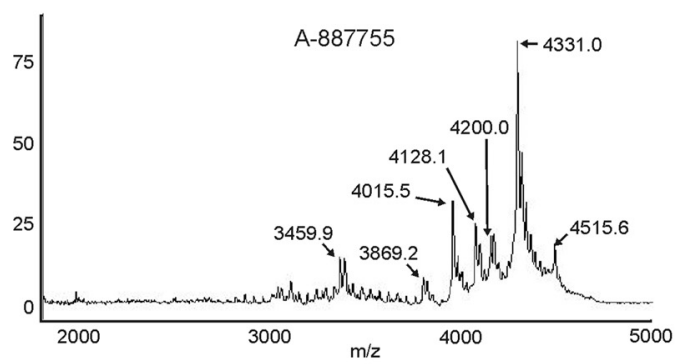

C

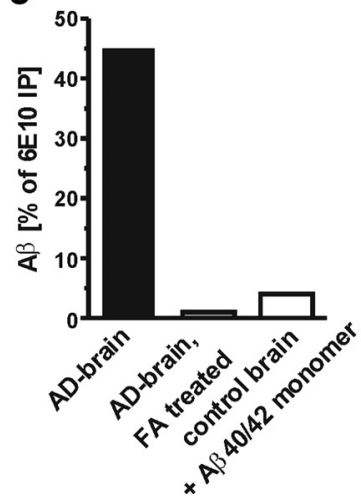

d

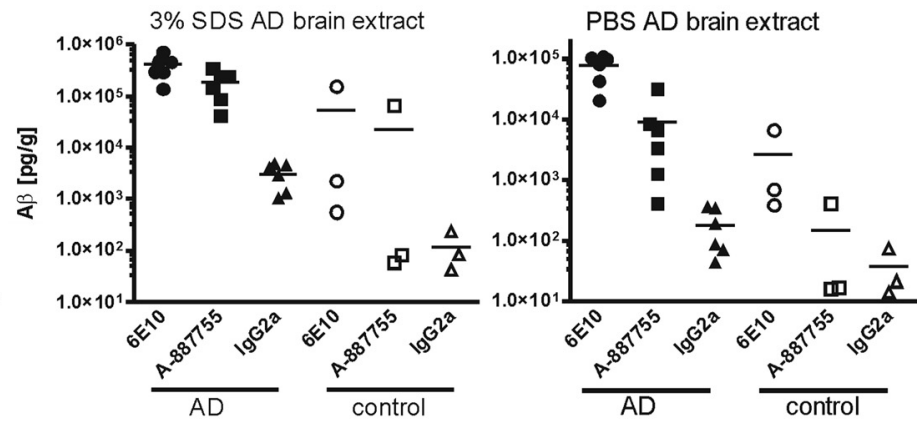

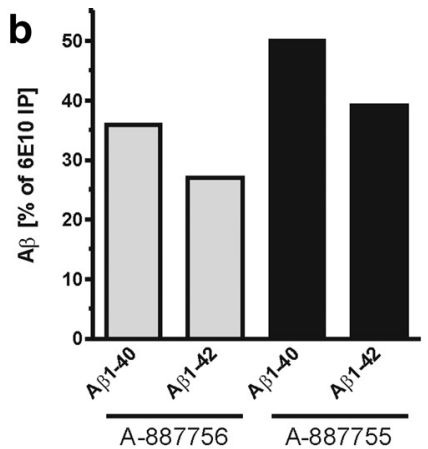

e

\begin{tabular}{c|c|c}
$\begin{array}{c}\text { found mass } \\
(\mathbf{k D a})\end{array}$ & $\begin{array}{c}\text { theoretical mass } \\
(\mathbf{k D a})\end{array}$ & $\begin{array}{c}\text { assigned } \\
\mathrm{AB} \text {-peptide }\end{array}$ \\
\hline 3459.9 & 3458.9 & $\mathrm{~A} \beta 3-40$ \\
\hline 3869.2 & 3867.4 & $\mathrm{~A} 35-40$ \\
\hline 4015.5 & 4014.5 & $\mathrm{~A} \beta 440$ \\
\hline 4128.1 & 4127.7 & $\mathrm{~A} \beta 441$ \\
\hline 4200.0 & 4198.8 & $\mathrm{~A} \beta 442$ \\
\hline 4331.0 & 4329.8 & $\mathrm{~A} \beta 1-40$ \\
\hline 4516.6 & 4514.1 & $\mathrm{~A} \beta 1-42$
\end{tabular}

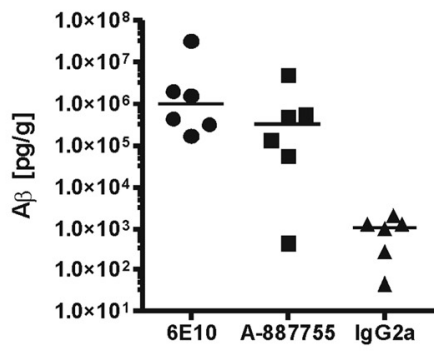

Figure 2. Binding of A-887755 in brain tissue of AD patients and APP transgenic mice ex vivo. $a, A \beta_{20-42}$ globulomer-selective antibody A-887755 immunoprecipitates a variety of soluble $N$ - and C-terminally truncated but also full-length $A \beta_{1-40}$ and $A \beta_{1-42}$ peptides as shown by SELDI-MS analysis of a 3\% SDS AD brain extract. Longer APP fragments like the $\beta$ stub C99 were not precipitated by $A-887755 . \boldsymbol{b}$, Quantification of $A \beta_{1-40}$ and $A \beta_{1-42}$ by $A \beta$ globulomer-selective antibodies $A-887756$ and $A-887755$, expressed as the fraction of the total amount of the respective $A \beta$ peptide in the $3 \%$ SDS extract of a representative AD brain determined by immunoprecipitation with the less selective antibody 6E10. $c$, The epitope recognized by A-887755 (black column) can be destroyed by pretreatment with formic acid (FA) (gray column). This epitope is not generated by adding synthetic $A \beta$ monomer before the $3 \%$ SDS extraction to a control brain (white column), suggesting that A-887755 selectively recognizes an epitope present in endogenous A $\beta$ oligomers. $\boldsymbol{d}$, , Soluble A $\beta$ levels determined by immunoprecipitation of $3 \%$ SDS and PBS extracts of AD brain (filled symbols; $n=6)$ and control brain (open symbols; $n=3)(\boldsymbol{d})$, and a 3\% SDS extract of the hippocampus of 10-month-old Tg2576 mice $(n=6)(\boldsymbol{e})$. Total A $\beta$ levels and oligomeric A $\beta$ levels were obtained with nonspecific $6 \mathrm{E} 10$ (circles) and globulomer-selective A-887755 (squares), respectively. Nonspecific background levels were determined by binding of a non-A $\beta$-reactive lgG2a isotype antibody (triangles) that was higher in AD brain because of higher total $A \beta$ peptide levels. For clinical and pathophysiological characterization of the AD samples, see supplemental Table 1 (available at www.jneurosci.org as supplemental material).

mushroom-like spines. At least three proximal (proximal dendrites, 30 $120 \mu \mathrm{m}$ from soma) and three distal dendritic segments (distal dendrites, $220-340 \mu \mathrm{m}$ from soma) were quantified in each neuron. Spines located on proximal dendrites and spines located on distal dendrites were analyzed separately. Statistical analysis of the spine density was performed with the average of the total number of spines per micrometers per neuron of each mouse/group.

Statistical analysis. Averaged data are calculated and shown as means \pm SEM. For evaluation of statistical differences, data were checked for normal distribution (Prism; GraphPad Software) and compared by parametric or nonparametric ANOVA. Thus, a nonparametric KruskalWallis test followed by Dunn's test was performed for the electrophysiological study. Most other studies were analyzed by ANOVA, followed by post hoc Bonferroni's $t$ test. For the dynamin cleavage study, a two-way ANOVA followed by post hoc Holm-Sidak test was used, and, for the water maze test, a three-way-ANOVA was used (see above). A level of $p<$ 0.05 was considered significant.

\section{Results}

Oligomer-selective antibodies by immunization with

N-terminally truncated $\mathbf{A} \boldsymbol{\beta}_{\mathbf{2 0 - 4 2}}$ globulomer

We had described previously a synthetic $\mathrm{A} \beta_{1-42}$ oligomer preparation that contains exclusively one biochemically defined oligomeric species and is not contaminated with $\mathrm{A} \beta_{1-42}$ monomers or $\mathrm{A} \beta_{1-42}$ fibrils (Barghorn et al., 2005). We used this preparation, named $\mathrm{A} \beta_{1-42}$ globulomer (Fig. 1a), to raise oligomer-specific mouse monoclonal antibodies. However, most of the resulting antibodies were directed against the hydrophilic flexible and less structure-defining $\mathrm{N}$-terminal part of the $\mathrm{A} \beta$ peptide shared by all $A \beta$ sequence-containing species. Antibody $6 \mathrm{G} 1$ is an example of this type of antibody and not able to discriminate between monomers, oligomers, or fibrils of $\mathrm{A} \beta$ (Fig. $1 b$ ). After cleaving the $\mathrm{N}$ terminus by limited proteolysis, a more condensed and hydrophobic oligomer, $\mathrm{A} \beta_{20-42}$ globulomer, was obtained (Fig. 1a). This truncated globulomer presented an epitope for raising antibodies that were now able to discriminate between $\mathrm{A} \beta$ oligomer and all other $\mathrm{A} \beta$ species, especially monomers and fibrils, and soluble APP in dot blot assays (Fig. 1b). Biacore binding analysis for the most specific antibody, A-887755, on $\mathrm{A} \beta_{20-42}$ globulomer immobilized sensor chips demonstrated a high-affinity binding for the antigen $\left(K_{\mathrm{D}}\right.$ of $1.56 \mathrm{nM} ; k_{\mathrm{on}}=9.37 \times 10^{5} \mathrm{M}^{-1} / \mathrm{s}^{-1}$ and $k_{\text {off }}=$ $\left.1.46 \times 10^{-4} \mathrm{~s}^{-1}\right)$.

Monoclonal antibody A-887755 selectively binds soluble A $\beta$ oligomers in brain tissue extracts from AD patients and APP transgenic mice

Although the specificity of the anti-globulomer antibodies is a very interesting in vitro property, the most relevant question was the ability of these antibodies to detect natural $\mathrm{A} \beta$ species in vivo. We used the most specific antibody, A-887755 (Fig. 1b), to immunoprecipitate soluble $\mathrm{A} \beta$ from the neocortex of an $\mathrm{AD}$ patient and analyzed the precipitated $\mathrm{A} \beta$ species using SELDI-MS. Al- 
though A-887755 was highly specific for the truncated $\mathrm{A} \beta_{20-42}$ globulomer in the dot blot assay in vitro, it was also able to bind to natural soluble $\mathrm{A} \beta_{1-42}, \mathrm{~A} \beta_{1-40}$, and $\mathrm{A} \beta_{(x-40,42)}$ species of various length in the $3 \%$ SDS AD brain extract (Fig. $2 a$ ). When we compared the amount of $\mathrm{A} \beta$ detected by the $\mathrm{A} \beta_{20-42}$ globulomerderived antibodies in the extract with the amount of $\mathrm{A} \beta$ detected by the conformation-independent $\mathrm{A} \beta$ antibody $6 \mathrm{E} 10$ (Fig. 1b), for $A \beta_{1-40}$ and $A \beta_{1-42}$, a fraction of between 25 and $50 \%$ of total soluble $\mathrm{A} \beta$ was found to bind to A- 887755 and $\mathrm{A}-887756$ (Fig. $2 b$ ). The in vitro highly selective antibody A- 887755 was considered most interesting and subsequently further characterized. In vivo oligomer specificity was tested by comparing A-887755immunoprecipitated soluble $\mathrm{A} \beta$ from $\mathrm{AD}$ brain extracts with $6 \mathrm{E} 10$ immunoprecipitation, the latter binding to all soluble $\mathrm{A} \beta$ species. When the $3 \%$ SDS brain extract was pretreated with formic acid, the secondary structure of the $\mathrm{A} \beta$ oligomers was destroyed. As a consequence, A-887755 was no longer able to detect extracted soluble $\mathrm{A} \beta$, although $6 \mathrm{E} 10$ did (Fig. $2 c$, first two bars). Because globulomer is generated by incubation with SDS in vitro, we checked the possibility that $\mathrm{A} \beta$ detected by $\mathrm{A}-887755$ had been freshly generated during extraction. Therefore, synthetic A $\beta$ monomer was spiked into and incubated with a 3\% SDS extract of a non-AD brain before homogenization and immunoprecipitation. This procedure did not result in $\mathrm{A} \beta$ that could be precipitated by A-887755, although $6 \mathrm{E} 10$ detected spiked $\mathrm{A} \beta$ as expected (Fig. 2c, right bar), suggesting that the $\mathrm{A} \beta_{20-42}$ globulomer-derived antibody A-887755 specifically binds to oligomeric $\mathrm{A} \beta$ without detecting $\mathrm{A} \beta$ monomer even when present far in excess over oligomers. For quantification of the amount of $\mathrm{A} \beta$ oligomers in $\mathrm{AD}$ and control brains, formic acid extracts could not be used because this procedure destroys oligomers. Therefore, we only used both PBS and 3\% SDS extracts to study the amount of soluble $\mathrm{A} \beta$ oligomers immunoprecipitated with $6 \mathrm{E} 10, \mathrm{~A}-887755$, and a non-A $\beta$-binding IgG2a control antibody in several $\mathrm{AD}$ and control brains. Although the concentration of total soluble $\mathrm{A} \beta$, as detected by $6 \mathrm{E} 10$, was $\sim 75 \mathrm{ng} / \mathrm{g}$ in the $\mathrm{PBS}$ extract, approximately fivefold more $\mathrm{A} \beta$ was extracted with $3 \%$ SDS, probably because of dissolving additional lipid-bound $\mathrm{A} \beta$. In comparison, the amount of soluble $A \beta$ oligomers, as detected by $A-887755$, was a significant fraction of total $A \beta$ in the PBS (12\%) and 3\% SDS (48\%) extracts (Fig. 2d). Importantly, APP transgenic mice also generate A-887755-detectable $\mathrm{A} \beta$ oligomers and are therefore suitable for testing antibody efficacy by neutralization of these oligomers (Fig. 2e). The fraction of SDS-soluble $\mathrm{A} \beta$ oligomers in Tg2576 brain is lower (16\%) as in the brain of $\mathrm{AD}$ patients.

\section{A-887755 does not bind to $\mathrm{A} \beta$ monomer or amyloid ex vivo} We next evaluated whether A-887755 detects $A \beta$ monomer or deposited $\mathrm{A} \beta$ in vivo. The ex vivo discrimination of $\mathrm{A}-887755$ to $\mathrm{A} \beta$ monomer was obtained in CSF and plasma of several AD and age-matched control patients. Although $6 \mathrm{E} 10$ detected $\mathrm{A} \beta$ in both fluids, A- 887755 was not able to detect more material than a non-A $\beta$-binding IgG isotype control antibody (Fig. $3 a$ ), suggesting that free soluble $\mathrm{A} \beta$ oligomers do not exist in CSF and plasma above a concentration of $5 \mathrm{pg} / \mathrm{ml}$, which was the detection limit of our method. Following the idea that $\mathrm{A} \beta$ oligomers might be associated with lipids that might hinder A-887755 immunoprecipitation, we added $3 \%$ SDS to CSF in analogy to the extraction of $A \beta$ oligomers from Alzheimer's disease brain. Nevertheless, this did not lead to any detectable immunoprecipitation of $\mathrm{A} \beta$ oligomers with A-887755, although the $\mathrm{A} \beta$ unselective antibody $6 \mathrm{E} 10$ was capable of immuno-
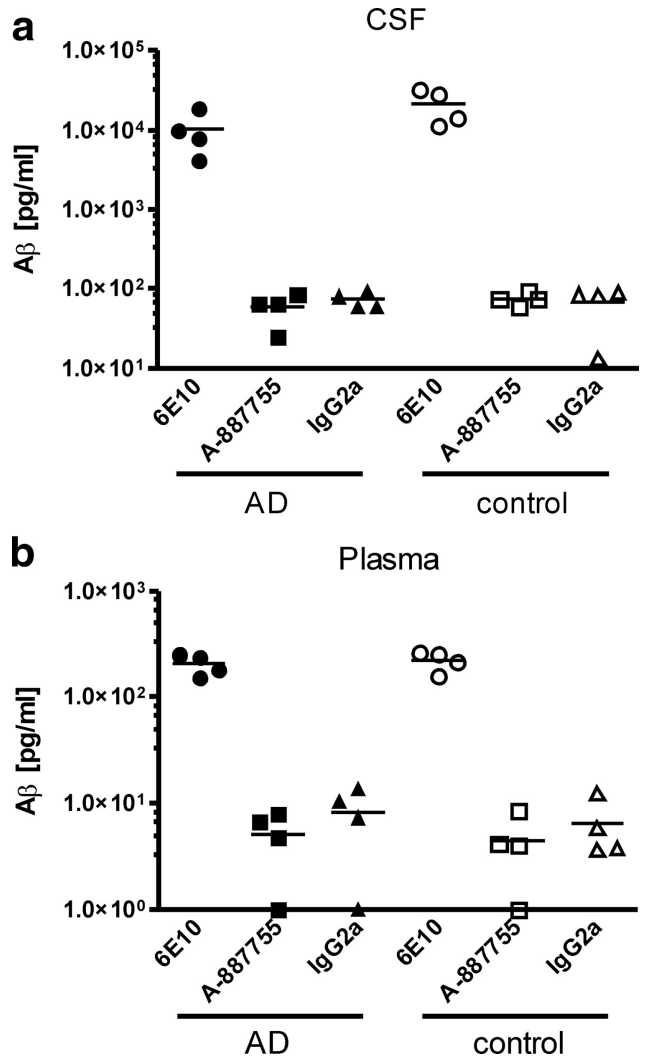

Figure 3. $A-887755$ does not bind to $A \beta$ monomer in vivo. Soluble $A \beta$ levels determined by immunoprecipitation of 3\% SDS extracts of CSF (a) and plasma ( $\boldsymbol{b}$ ) of AD patients (filled symbols; $n=4$ ) and age-matched controls (open symbols; $n=4$ ). Total $A \beta$ levels and oligomeric $A \beta$ levels were obtained with nonspecific 6 E10 (circles) and globulomer-selective A-887755 (squares), respectively. Nonspecific background levels were determined by binding of a nonA $\beta$-reactive lgG2a isotype antibody (triangles). The lack of A-887755 binding in CSF and plasma indicates absence of detectable levels of free $A \beta$ oligomers in these fluids and high selectivity of A-887755 versus abundant $A \beta$ monomer. For clinical and pathophysiological characterization of the AD samples, see supplemental Tables 2 and 3 (available at www.jneurosci.org as supplemental material).

precipitating monomeric $\mathrm{A} \beta$ peptide (data not shown; note that the $3 \%$ SDS had been suitably diluted before immunoprecipitation).

Then, we investigated the selectivity of A-887755 toward $\mathrm{A} \beta$ deposits. Conformation-independent $6 \mathrm{E} 10$ and $6 \mathrm{G} 1$ but not A- 887755 were able to bind to deposited $\mathrm{A} \beta$ in the parenchyma or vessels of $\mathrm{AD}$ patients (Fig. $4 a, b$ ). Binding of $6 \mathrm{E} 10$ and A-887755 was tested at various concentrations. Although $6 \mathrm{E} 10$ staining of $\mathrm{A} \beta$ deposits dose dependently increased, A-887755 did not bind to $A \beta$ deposits up to $7 \mu \mathrm{g} / \mathrm{ml}$ (Fig. $4 c$ ). Staining of Tg2576 mouse brains revealed a similar picture as observed in AD brain. Although 6E10 heavily stained amyloid plaques and smaller $\mathrm{A} \beta$ deposits, $\mathrm{A}-887755$ only showed background staining (Fig. $4 d$ ), again demonstrating that the antibody does not bind to deposited $\mathrm{A} \beta$. A histological cross-reactivity analysis with several tissues of cynomolgus monkey and humans did not result in any specific binding of FITC-labeled A-887755.

\section{A-887755 neutralizes A $\beta$ oligomer-derived neuropathogenic} effects in hippocampal neurons and slice cultures

We were then interested in the pathological effects of $A \beta_{20-42}$ globulomer and their neutralization by $\mathrm{A}-887755$. In a first step, we demonstrated binding of $\mathrm{A} \beta_{20-42}$ globulomer to rat primary hippocampal neurons (Fig. $5 a$ ). The punctuated specific binding to neurons was prevented by A- 887755 but not by a non-A $\beta$ - 
binding IgG isotype control antibody. Because this binding pattern is reminiscent of synaptic binding, we also studied evoked synaptic transmission in rat hippocampal slice cultures. Incubation with $\mathrm{A} \beta_{20-42}$ globulomer resulted in a significant decrease in the input/output curve. Preincubation of $\mathrm{A} \beta_{20-42}$ globulomer with A-887755 fully prevented the reduced synaptic transmission (Fig. 5b).

Dynamin, a protein involved in synaptic vesicle release, may be involved in $\mathrm{A} \beta$ oligomer-induced synaptic pathology because aggregated $\mathrm{A} \beta_{1-40}$ has been shown recently to induce cleavage of dynamin I in hippocampal neurons (Kelly et al., 2005; Kelly and Ferreira, 2006). Using densitometric analysis of $\beta$-tubulin-normalized protein level, we also observed a marked decrease in the amount of uncleaved dynamin I and a concomitant increase of the inactive cleavage product after incubation of hippocampal neurons with aggregated $\mathrm{A} \beta_{1-40}$ for $24 \mathrm{~h}$ (Fig. $5 c$ ). Preincubation of aggregated $\mathrm{A} \beta_{1-40}$ with $\mathrm{A}-887755$ completely prevented the dynamin I cleavage. In contrast, an IgG2a isotype control antibody did not provide any protection from cleavage (Fig. $5 c$ ).

\section{Vaccination with $\mathrm{A} \boldsymbol{\beta}_{20-42}$ globulomer mounts an $A \boldsymbol{\beta}$ oligomer-selective antibody response and normalizes cognition in APP/L mice}

To address the therapeutic potential of our $\mathrm{A} \beta$ oligomer-specific antibody in a preclinical model, we immunized 1.5-month-old APP/L mice with $\mathrm{A} \beta_{20-42}$ globulomer. The selectivity profile of the antibody response in the serum of each individual mouse was determined 3 months later by dot blot against decreasing amounts of the secreted form of APP (sAPP $\alpha), \mathrm{A} \beta_{1-40}$ monomer, $\mathrm{A} \beta_{1-42}$ monomer, $\mathrm{A} \beta_{1-42}$ fibrils, $\mathrm{A} \beta_{1-42}$ globulomer, and $\mathrm{A} \beta_{20-42}$ globulomer. The whole group of $\mathrm{A} \beta_{20-42}$ globulomer-immunized mice showed a very consistent antibody profile, indicating a very selective immune response toward the $\mathrm{A} \beta_{20-42}$ globulomer antigen without any crossreaction to other $\mathrm{A} \beta$ species (Fig. $6 a, b$ ). Thus, $\mathrm{A} \beta_{20-42}$ globulomer vaccination of APP/L mice resulted in a monospecific immune response with a similar selectivity profile as shown for A-887755 (Fig. 1b). In contrast, immunization with full-length $\mathrm{A} \beta_{1-42}$ globulomer and $\mathrm{A} \beta_{1-42}$ monomer resulted in a broadband antiserum comprising antibodies not only reacting against $\mathrm{A} \beta$ oligomers but also against monomers and $\mathrm{sAPP} \alpha$ in some mice (Fig. 6b), i.e., comparable with the selectivity profile of 6G1 (Fig. $1 b$ ). To assess the functional consequence of this endogenous antibody response, the mice were subjected to a novel object recognition task (Fig. $6 c$ ). The $\mathrm{A} \beta$ oligomer-specific immune response was able to normalize the inability of PBS-injected control $\mathrm{APP} / \mathrm{L}$ mice to recognize a new object. The $\mathrm{A} \beta$ oligomer-specific immune response was associated with the improved ability of APP/L mice to recognize a new object, suggesting that antibodies to other $\mathrm{A} \beta$ species or sAPP $\alpha$ are not necessary or may even prevent this effect (see $\mathrm{A} \beta_{1-42}$ monomer vaccination in Fig. $6 c$ ).

\section{A-887755 normalizes cognitive performance in APP/L mice}

To address the hypothesis that exogenous application of anti- $\mathrm{A} \beta$ oligomer antibodies has the same in vivo efficacy as vaccination, we treated 4.5- to 7-month-old APP/L mice with A-887755. The experiments were conducted at the age when cognitive differences between transgenic and nontransgenic mice had been found in previous studies but which was well before amyloid plaque deposition (Moechars et al., 1999; Dewachter et al., 2002). In the novel object recognition task, poor performance of the 4.5-month-old PBS-treated APP/L mice in the novel object recognition task was reversed by 3 week treatment with either the broadband $A \beta$ antibody $6 \mathrm{G} 1$ or the $\mathrm{A} \beta$ oligomer-selective antibody A-887755 (Fig. 7a). Again, the oligomer-selective anti-A $\beta$ immunotherapy was sufficient for reversing the $A \beta$-induced deficit. A second experiment evaluated effects of A- 887755 on learning in the water maze task. Although 7-month-old APP/L mice performed significantly worse than their wild-type controls, treatment with A- 887755 for $10 \mathrm{~d}$ before the starting the water maze training abolished the difference between transgenic and nontransgenic mice (Fig. 7b).

\section{A-887755 normalizes synaptic spine density in $\operatorname{Tg} 2576$ mice} Finally, we were interested in the anatomical basis of $A \beta$ oligomer pathology and its normalization by A- 887755 . As suggested by recent reports of pathogenic effects on synapses by $\mathrm{A} \beta$ oligomers in vitro (Lacor et al., 2007; Shankar et al., 2007), we focused on synaptic spine density in APP transgenic mice. Because we had identified a reduction of synaptic spines in 6-month-old Tg2576 mice, we injected A- 887755 for 3 weeks in 5-month-old mice of 

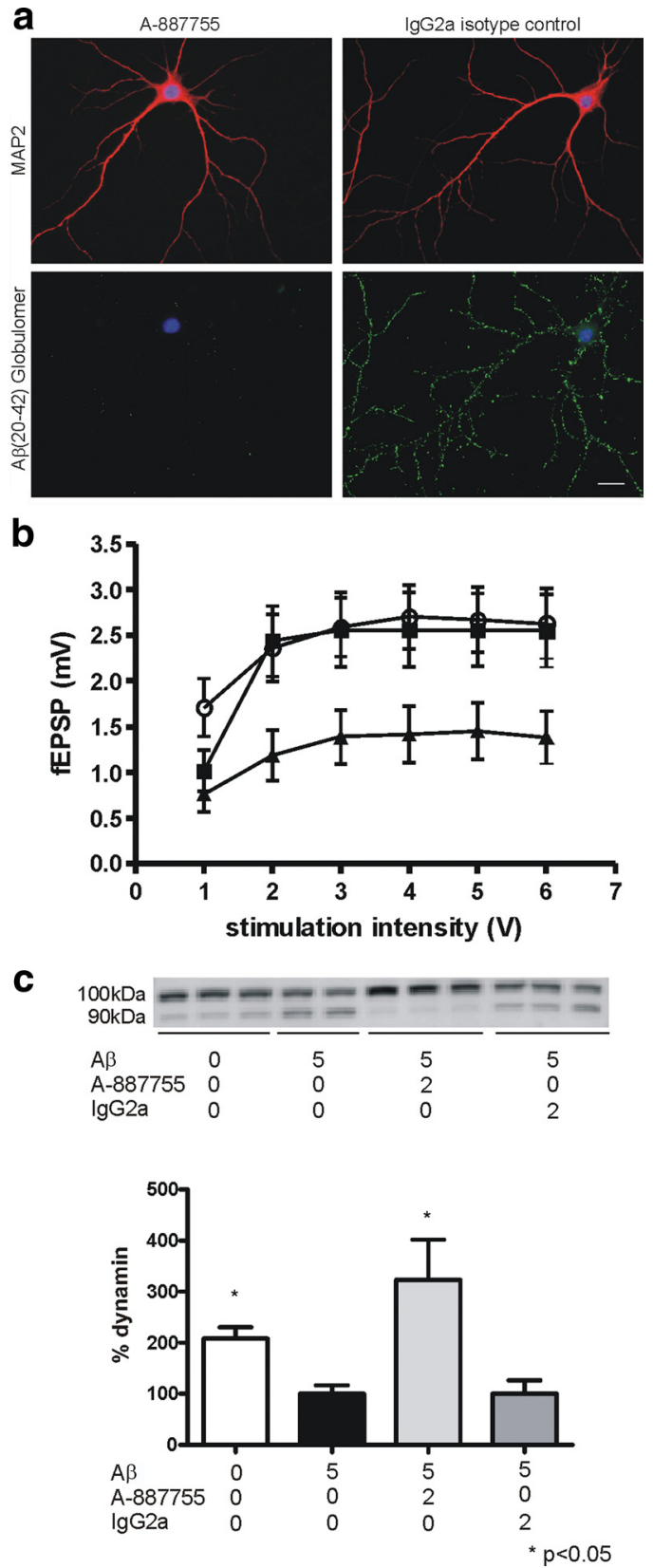

Figure 5. $\quad A \beta_{20-42}$ globulomer-derived antibodies neutralize $A \beta$ oligomer-derived neuropathogenic effects in hippocampal neurons and slices. $\boldsymbol{a}$, Incubation of A-887755 antibody with $\mathrm{A} \beta_{20-42}$ globulomer in a 2:1 molar ratio ( 8.3 nм $\mathrm{A} \beta_{20-42}$ globulomer/16.7 nм A-887755) prevents binding of the $A \beta_{20-42}$ globulomer to hippocampal neurons, in contrast to the $A \beta$ nonspecific isotype control lgG2a antibody. $\boldsymbol{b}$, Antibody A-887755 prevents synaptic deficits induced by $A \beta_{20-42}$ globulomer. Input/output relation was recorded in CA1 from slice cultures treated with $160 \mathrm{~nm} \mathrm{~A} \beta_{20-42}$ globulomer (filled triangles), 160 nм A $\beta_{20-42}$ globulomer plus 100 nм A-887755 (filled squares), or vehicle (open circles) for $24 \mathrm{~h}$. Globulomer-induced suppression was significant with $p=0.013$, reversal with $p=0.027$ (2-way repeated measures ANOVA with Holm-Sidak post hoc analysis). fEPSP, Field EPSPs. c, Antibody A-887755 protects hippocampal neurons against $A \beta$-induced dynamin cleavage. Top, Samples representing repeated experimental conditions from a single experiment are shown and treatment concentrations (in $\mu \mathrm{m}$ ) are indicated below. (ells without addition of $A \beta$ show mostly intact $(\sim 100 \mathrm{kDa})$ dynamin I signals, which is decreased and reverted to an $\sim 90 \mathrm{kDa}$ cleavage product in cells treated with $5 \mu \mathrm{m} \mathrm{A} \beta$. Antibody A-887755 treatment reverts the cleavage, whereas an IgG2a control antibody is without a pronounced protective effect. Bottom, Quantification of the dynamin signal of three independent experiments (expressed as percentage dynamin \pm SEM after normalization to $5 \mu \mathrm{m} A \beta$ treatment) revealed a statistically significant protective effect of $A-887755$ (oneway ANOVA, Kruskal-Wallis test followed by Dunn's test; ${ }^{*} p<0.05$ ). this strain and quantified the synaptic spine density in hippocampal CA1 by Golgi staining. In the basal dendrites of pyramidal neurons, a reduced density of synaptic spines was observed that was normalized by A- 887755 treatment (Fig. $8 b$ ). A quantitative analysis revealed a significantly reduced synaptic spine density in the basal but not the apical CA1 pyramidal dendrites of Tg2576 mice that was normalized in the proximal part of the dendrites by A-887755 (Fig. 8a).

\section{Discussion}

Our understanding of the neuropathology of $\mathrm{A} \beta$ has changed considerably with the accumulating evidence that $A \beta$ oligomers are probably the most neuropathogenic $\mathrm{A} \beta$ species for synapses and cognition (Walsh and Selkoe, 2007). Toxic A $\beta$ oligomers of different size have been studied, and the smallest apparent oligomeric species of $A \beta$ in SDS-PAGE, a dimer, has been isolated recently from $\mathrm{AD}$ brain and its pathology demonstrated in preclinical AD models (Shankar et al., 2008). Toxicity of quite different $\mathrm{A} \beta$ oligomers raise the important question if size, i.e., $\mathrm{A} \beta$ dimer, dodecamer, or any other multimer size, is the main characteristic for its neuropathogenic nature or whether $\mathrm{A} \beta$ becomes toxic because of a conformational switch triggering subsequent formation of various misfolded $\mathrm{A} \beta$ oligomers structurally different from $\mathrm{A} \beta$ monomer or fibril. $\mathrm{A} \beta$ oligomer-containing brain extracts of AD patients (Shankar et al., 2008) or APP transgenic mice (Lesné et al., 2006) provided strong evidence for the toxic nature of $\mathrm{A} \beta$ oligomers but could not reveal their neuropathologic mechanism. The idea to study this mechanism by synthetic $\mathrm{A} \beta$ oligomers was first addressed with the ADDL preparation (Lambert et al., 1998). However, ADDLs turned out as a mixture of $A \beta$ oligomers of different size and residual $A \beta$ monomer, which could not answer the question of size or conformation of $\mathrm{A} \beta$ oligomer neuropathology. To test the conformation hypothesis, we have introduced $\mathrm{A} \beta_{1-42}$ globulomer as a homogenous and stable oligomer (Barghorn et al., 2005). Although the hypothesis of a different conformation to $\mathrm{A} \beta$ monomer and fibril was supported by the demonstration of separate aggregation pathway in vitro (Gellermann et al., 2008), $\mathrm{A} \beta_{1-42}$ globulomer did still produce antibodies such as $6 \mathrm{G} 1$ that detected all $\mathrm{A} \beta$ species, including $\operatorname{sAPP} \alpha$. We hypothesized that this was attributable to the $\mathrm{N}$-terminal sequence of $\mathrm{A} \beta$ shared by all these species and therefore removed hydrophilic N-terminal amino acids by limited proteolysis. This procedure resulted in a poorly soluble $\mathrm{A} \beta_{20-42}$ globulomer, which, however, had the advantage of mounting a monospecific antibody response in APP transgenic mice yielding highly $\mathrm{A} \beta$ oligomer-selective monoclonal antibodies such as A-887755. This antibody bound only to $A \beta_{20-42}$ globulomer but not to $A \beta_{1-42}$ globulomer in dot blots, suggesting recognition of $\mathrm{N}$-terminally truncated $\mathrm{A} \beta$ oligomers only. However, when using AD and APP transgenic mouse brain extracts, A-887755 was able to detect full-length $A \beta$, suggesting that synthetic $\mathrm{A} \beta_{1-42}$ globulomer is very tightly packed, leaving no access for antibodies that bind to regions beyond amino acid 20. In fact, antibodies generated with synthetic $\mathrm{A} \beta_{20-42}$ globulomer were able to exclusively bind to misfolded $\mathrm{A} \beta$ oligomers in $\mathrm{AD}$ brain tissue, both full-length and truncated, but not to $A \beta$ monomer or fibrils, even when highly abundant as in CSF or amyloid plaques, respectively. Thus, $\mathrm{A} \beta_{20-42}$ globulomer and A- 887755 were identified as excellent tools to address the following questions: (1) what is the structural basis of the special neuropathologic conformation of $\mathrm{A} \beta$ oligomers, (2) how abundant are the neuropathogenic $\mathrm{A} \beta$ oligomers in the brain of $\mathrm{AD}$ patients, and (3) does 


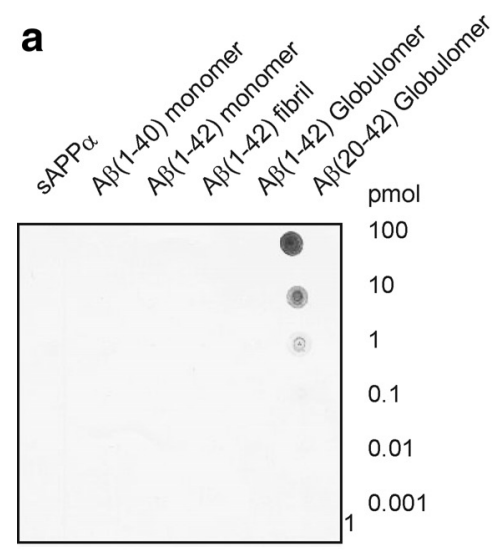

\section{b}
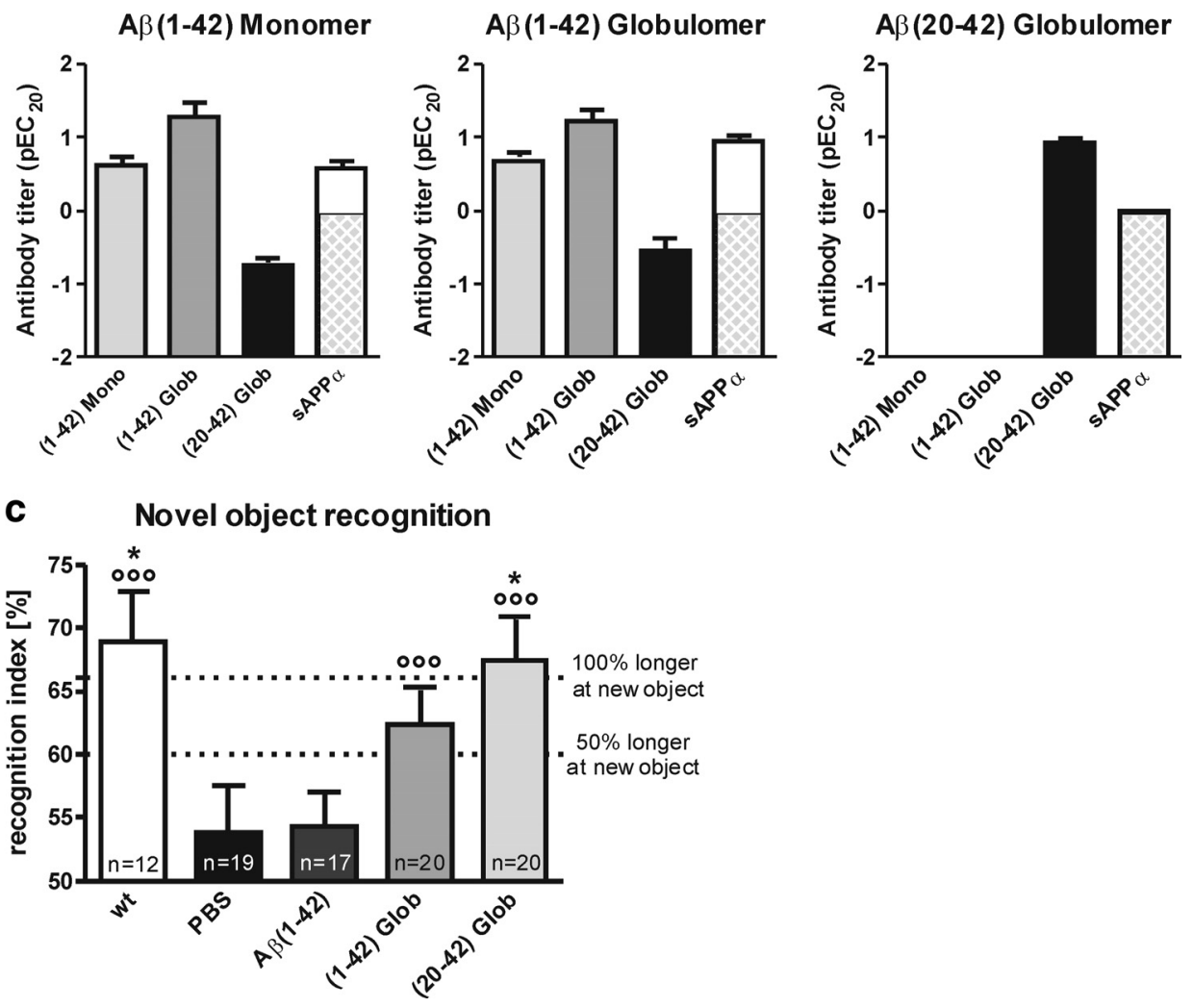

Figure 6. Oligomer-specific antibodies generated by vaccination with $A \beta 20-42$ globulomer in APP/L mice improve cognition. $\boldsymbol{a}$, Active immunization with $A \beta_{20-42}$ globulomer reproducibly mounts an oligomer-specific antibody response. Representative dot blot of the antiserum from an APP/L mouse immunized with $A \beta_{20-42}$ globulomer shows that the immune response is highly selective for $A \beta$ globulomer and resembles that of $A-887755$. $\boldsymbol{b}$, Specific titers of antibodies in $A P P / L$ mice from active immunization with $A \beta_{1-42}$ monomer, $A \beta_{1-42}$ globulomer, and $A \beta_{20-42}$ globulomer. Immunization results in titers for $A \beta_{1-42}$ monomer (light gray bars), $A \beta_{1-42}$ globulomer (dark gray bars), $A \beta_{20-42}$ globulomer (black bars), and sAPP $\alpha$ (white bars). Data are relative titers expressed as $\mathrm{pEC}_{20}$ (in picomoles) $\pm \mathrm{SEM}$. Detection limit for the monomer and globulomer of $\mathrm{A} \beta$ was $100 \mathrm{pmol}\left(\mathrm{pEC} \mathrm{C}_{20}=-2\right.$ ) and for sAPP $\alpha$ was $1 \mathrm{pmol}$ ( $\mathrm{pEC} 20=0$; therefore, remaining bar below 0 cross-hatched shaded). Although $A \beta_{1-42}$ monomer and globulomer raised antibodies against all species, including sAPP $\alpha, A \beta_{20-42}$ globulomer mounted an antibody response specific for the globulomer ( $A \beta$ oligomer) epitope. $c$, $A c$ ctive immunization with $A \beta_{20-42}$ globulomer improves performance in the novel object recognition task. Performance in novel object recognition of these mice [wild type (wt), white bars; APP/L, black and gray bars]. Recognition index was calculated as the time spent with exploring the new compared with both objects (e.g., 66\% meaning double as long for the new object). Data are means \pm SEM of the number of animals indicated in the bars. Statistical differences were calculated by ANOVA ( $p<0.01)$, followed by post hoc Bonferroni's $t$ test $\left({ }^{*} p<0.05\right.$ vs PBS). Circles indicate significant recognition of new objects above chance level (i.e., $\left.50 \% ;{ }^{\circ 00} p<0.001\right)$.

neutralization of this oligomeric $\mathrm{A} \beta$ conformer provide therapeutic efficacy in preclinical models of $\mathrm{AD}$ ?

Assuming a conformational change as the basis of $\mathrm{A} \beta$ oligomer neuropathology, our data suggest that the relevant structural motif is located in the $\mathrm{C}$-terminal part of the $\mathrm{A} \beta$ sequence between amino acids 20 and 42 . Previous work by Teplow et al. (2006) hint to an $\mathrm{A} \beta_{21-30}$ loop region that may distinguish $\mathrm{A} \beta$ monomer, oligomers, and fibrils. We have recently analyzed the globulomer structure by nuclear magnetic resonance and found that the characteristic globulomer epitope is formed by a loop consisting of amino acids $20-30$ and that A-887755 particularly binds to this loop (Yu et al., 2009). The change of A $\beta$ conformation from the nonpathogenic monomer to the globulomer likely relies on additional factors such as lipids or lipoproteins (Barghorn et al., 2005), e.g., apolipoprotein E (Tokuda et al., 2000 ). Why and when the pathological event of $A \beta$ misfolding takes place in Alzheimer's disease will be a most interesting question for additional studies with our conformation-dependent antibody. So far, we have observed highly specific binding of A- 887755 only to $A \beta$ oligomer but not to any other physiological or misfolded peptide, such as $\alpha$-synuclein, which is in contrast to the binding of antibody A11 to several misfolded proteins (Kayed et al., 2003).
Another important question addressable by A- 887755 is the amount and distribution of neuropathogenic $A \beta$ oligomer in the brain. The monoclonal antibody does not detect the abundant $\mathrm{A} \beta$ monomers in CSF nor the accumulating deposited $\mathrm{A} \beta$ fibrils in brain tissue. Therefore, all peptides in brain extracts detected by the monoclonal antibody were misfolded $\mathrm{A} \beta$ peptides. Initially, this conformational switch of the loop comprising amino acids 20-30 may occur at the monomeric state, but our data suggest that this change from physiological to the pathological state is immediately stabilized by oligomerization. Compared with the total amount of $\mathrm{A} \beta$ peptides in brains of $\mathrm{AD}$ patients or aged APP transgenic mice, the soluble oligomer fraction is small. Our data demonstrate, however, that in SDS extractable material of disease brain, containing only soluble $\mathrm{A} \beta$ peptides, up to $50 \%$ of total $\mathrm{A} \beta$ was detected by $\mathrm{A}-887755$. The remaining $50 \%$ of total $\mathrm{A} \beta$ may not have been detected because these were $\mathrm{A} \beta$ monomers, $\mathrm{A} \beta$ oligomers in a different conformation, or inaccessible for A- 887755 because the antibody binding region was occupied by lipids or other binding partners. When comparing the binding of A-887755 with PBS and SDS extracts, extraction with 3\% SDS increased the soluble fraction of the presumably neuropathogenic oligomers, suggesting that they are not freely diffusible but rather associated with membrane components or 


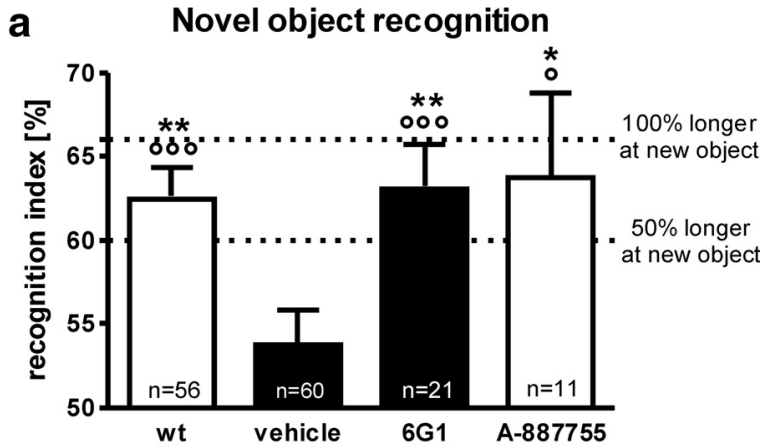

b

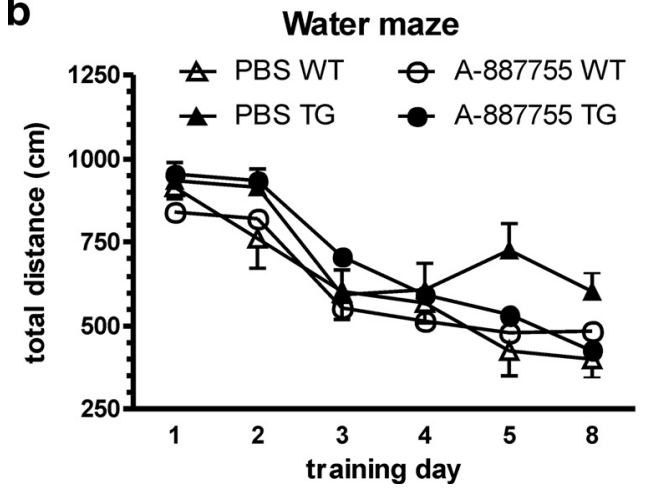

Figure 7. Oligomer-specific A-887755 improves cognitive performance in APP/L mice. $\boldsymbol{a}$, Treatment with the oligomer-specific A-887755, rather than with less $A \beta$ oligomer-selective antibodies, is sufficient to improve performance in the novel object recognition task. In the novel object recognition test of APP/L mice [wild type (wt), white bars; APP/L, black and gray bars] recognition index was calculated as the time spent with exploring the new compared with both objects (e.g., $66 \%$ meaning double as long for the new object). Data are means \pm SEM of the number of animals indicated in the bars. Statistical differences were calculated by ANOVA $(p<0.01)$, followed by post hoc Bonferroni's $t$ test $\left({ }^{*} p<0.05,{ }^{* *} p<0.01\right.$ vs PBS). Circles indicate significant recognition of new objects above chance level (i.e., $50 \% ;{ }^{\circ} p<0.05,{ }^{\circ 00} p<$ 0.001). Treatment with the $A-887755$ antibody eliminated the difference between transgenic and wild-type mice. $\boldsymbol{b}$, Treatment with the oligomer-specific A-887755 improves learning in the water maze. In the Morris water maze over the days of training, mice learned to find the submerged platform, and this learning was reflected in the overall main effect of time revealed by ANOVA $\left(F_{(5,287)}=3.4, p<0.01\right)$. After several days of training, wild-type (WT) control animals substantially improved and swam shorter distances to the platform, and these traveled distances were shorter than those in transgenic (TG) mice treated with PBS. Treatment with the A-887755 antibody eliminated the difference between transgenic and wild-type mice as suggested by the genotype $X$ treatment $\times$ time interaction $\left(F_{(5,287)}=2.4, p<0.05\right)$.

matrix proteins in vivo. This is supported by the lack of binding to biological fluids, i.e., no A $\beta$ globulomer epitope detection above detection limit of $5 \mathrm{pg} / \mathrm{ml}$ for plasma and $70 \mathrm{pg} / \mathrm{ml}$ for CSF. If misfolded $\mathrm{A} \beta$ oligomers were freely diffusible, $\mathrm{A}-887755$ would have been able to detect them in the CSF. The fact that a small amount of $\mathrm{A} \beta$ oligomers can be extracted by PBS and that they are enriched in the extracellular fraction (Lesné et al., 2006) suggests that they are weakly attached on the extracellular side. Specific binding of $\mathrm{A} \beta$ oligomers to neurons is suggested by the binding of the synthetic $A \beta_{20-42}$ globulomer and ADDLs (Lacor et al., 2007) to hippocampal neurons. Recently, it has been shown that that presence of collagen VI prevents binding of $A \beta$ oligomers to neurons, suggesting a high affinity to extracellular matrix protein (Cheng et al., 2009). We have also observed a strong binding of poorly soluble $A \beta_{20-42}$ globulomer to extracellular matrix proteins such as laminin and collagen (our unpublished observation). It is therefore conceivable that not only formation of neuropathogenic $\mathrm{A} \beta$ oligomers is dependent on lipids but that oligomers also bind to lipids and extracellular matrix at the site of
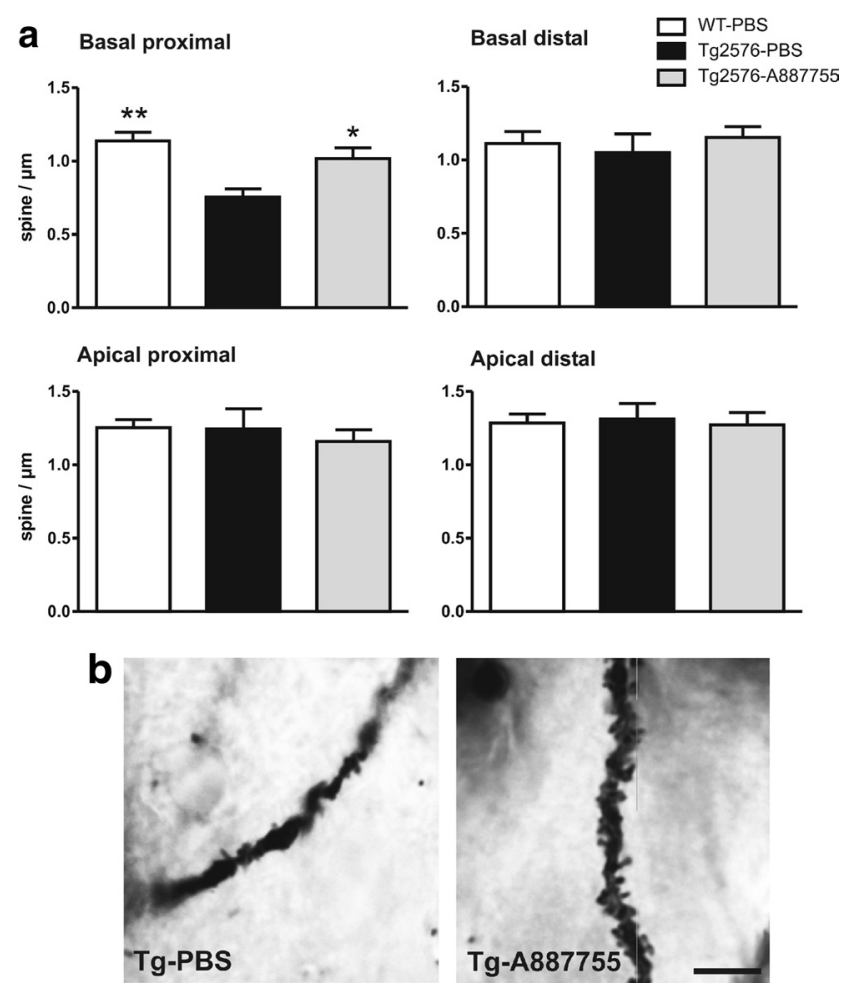

Figure 8. Oligomer-specific A-887755 improves synaptic spine density in $\mathrm{Tg} 2576$ mice. Fivemonth-old APP transgenic Tg2576 or nontransgenic control mice were intraperitoneally injected with $500 \mu \mathrm{g}$ of A-887755 or PBS (vehicle) once weekly for 3 weeks. Three days after the last injection, the animals' brains were Golgi stained for reconstruction of neuronal morphology. The density of dendritic mushroom-type spines of CA1 pyramidal cells was quantitatively analyzed. $\boldsymbol{a}$, Quantitative analysis of spine density in basal proximal dendrites (30-120 $\mu \mathrm{m}$ from soma) showed a significant reduction of mushroom-type spines in $\mathrm{Tg} 2676$ mice that was reversed by A-887755 (ANOVA, $F_{(2,173)}=8.75, p<0.05$; post hoc Bonferroni's $t$ test, ${ }^{*} p<$ $\left.0.05,{ }^{* *} p<0.01\right)$. Spine density was not changed in other parts of the CA1 pyramidal neuron dendrites. WT, Wild type. $\boldsymbol{b}$, Golgi-stained basal dendrite of two Tg2576 mice treated with PBS or with A-887755. Scale bar, $10 \mu \mathrm{m}$.

generation and are widely distributed in contrast to fibrillar $\mathrm{A} \beta$ in plaques. This, however, does not preclude that the concentration of $\mathrm{A} \beta$ oligomers can be highest around the plaques (Koffie et al., 2009 ) and that endogenous $A \beta$ oligomers may serve as a seeding core for plaque formation (Meyer-Luehmann et al., 2006; Shankar et al., 2008). The comparison of the effects of A- 887755 with that of conformation-independent anti-A $\beta$ antibodies will help to better understand a potential interaction between plaque and oligomertype amyloid deposits.

Toxicity of $\mathrm{A} \beta$ oligomers has been reported to be closely associated with synapses. Synthetic and natural $A \beta$ oligomer preparations bind to synaptic sites on hippocampal neurons and interfere with synaptic transmission (Lacor et al., 2004, 2007; Shankar et al., 2007). This interaction is considered the pathological basis of dementia in $\mathrm{AD}$ and of morphological and functional deficits in APP transgenic mice (Walsh and Selkoe, 2007). A $\beta$ immunotherapy has been used in the past to improve cognitive function in APP transgenic mice (Dodart et al., 2002; Hartman et al., 2005). Although the previously used conformationindependent antibodies, e.g., 266 or 10D5, should be able to neutralize $\mathrm{A} \beta$ oligomers, part of their efficacy may have been associated with binding to deposited fibrillar or soluble monomeric A $\beta$ (Seubert et al., 2008). A-887755 or the oligomerspecific polyclonal antibodies after active vaccination were also efficacious in improving cognitive function in APP transgenic 
mice, demonstrating that selective neutralization of $\mathrm{A} \beta$ oligomers is sufficient to obtain this effect. The striking reduction of synaptic spines by $\mathrm{A} \beta$ oligomers in hippocampal neurons as a morphological substrate of reduced cognitive function was reversed by antibody $6 \mathrm{E} 10$, which recognizes all $\mathrm{A} \beta$ species with intact $\mathrm{N}$ terminus (Shankar et al., 2007). We have shown a similar reduction of synaptic spines in hippocampal CA1 dendrites in APP transgenic mice. A- 887755 was able to partially reverse this deficit, confirming that an $\mathrm{A} \beta$ oligomer-selective treatment is sufficient to ameliorate neuropathology. Amyloid plaque removal seems unable to stop ongoing dementia in AD patients (Holmes et al., 2008). Thus, neutralization of $A \beta$ oligomers appears to be a more attractive primary focus of $A \beta$ immunotherapy. If effective immunotherapy is achieved by neutralization of misfolded $\mathrm{A} \beta$ oligomers, a conformation-independent anti-A $\beta$ antibody might have some unwanted side effects. Binding to continuously generated $\mathrm{A} \beta$ monomers will consume these antibodies and reduce their ability to neutralize the less abundant $A \beta$ oligomers. Binding to fibrillar $\mathrm{A} \beta$ will remove plaques but may also increase the risk of inflammatory responses, such as microhemorrhages in APP transgenic mice or vasogenic edema in AD patients (Pfeifer et al., 2002; Racke et al., 2005). A number of anti-A $\beta$ oligomer-selective antibodies have been described, but they have limitations because they are polyclonal like the A11 antibody (Kayed et al., 2003) or they clearly recognize fibrillar A $\beta$ as well and still bear the associated side-effect risk (Lee et al., 2006, Lambert et al., 2007). Strictly A $\beta$ oligomer-specific monoclonal antibodies such as A-887755 that are devoid of any monomer or fibril binding will be extremely helpful tools to fully evaluate the therapeutic potential of $\mathrm{A} \beta$ oligomer-selective immunotherapy. Although efficacy of A- 887755 by reducing soluble $A \beta$ oligomers has been demonstrated in APP transgenic mice before any plaque deposition, the clinical situation is quite different. The antibody has to prove its potency also in the presence of a high concentration of deposited $\mathrm{A} \beta$ and it will be interesting and important to test this in the preclinical mouse model.

In summary, the use of $A \beta_{20-42}$ globulomer allowed us to conclude that the neuropathogenic effect of $A \beta$ oligomers is based on a specific conformation rather than on a specific molecular weight. Using the globulomer conformation, we were able to generate the specific monoclonal antibody A-887755, which was helpful in demonstrating the presence of $A \beta$ oligomers in brain tissue of AD patients or APP transgenic mice but not in agematched nondiseased individuals. Finally, the improved spine density and cognitive function in APP transgenic mice after A-887755 treatment raises the hope that selective $\mathrm{A} \beta$ oligomer immunotherapy is a promising therapeutic approach without side effects associated with general anti-A $\beta$ therapy. In addition, the globulomer concept will assist in reaching a clearer understanding of the molecular mechanisms of $\mathrm{A} \beta$ oligomer pathology, like a recently described interference with the presynaptic P/Q-type calcium current (Nimmrich et al., 2008).

\section{References}

Barghorn S, Nimmrich V, Striebinger A, Krantz C, Keller P, Janson B, Bahr M, Schmidt M, Bitner RS, Harlan J, Barlow E, Ebert U, Hillen H (2005) Globular amyloid $\beta$-peptide oligomer: a homogenous and stable neuropathological protein in Alzheimer's disease. J Neurochem 95:834-847.

Bateman RJ, Munsell LY, Morris JC, Swarm R, Yarasheski KE, Holtzman DM (2006) Human amyloid- $\beta$ synthesis and clearance rates as measured in cerebrospinal fluid in vivo. Nat Med 12:856-861.

Cheng JS, Dubal DB, Kim DH, Legleiter J, Cheng IH, Yu GQ, Tesseur I, Wyss-Coray T, Bonaldo P, Mucke L (2009) Collagen VI protects neurons against $\mathrm{A} \beta$ toxicity. Nat Neurosci 12:119-121.
Dewachter I, Reversé D, Caluwaerts N, Ris L, Kuipéri C, Van den Haute C, Spittaels K, Umans L, Serneels L, Thiry E, Moechars D, Mercken M, Godaux E, Van Leuven F (2002) Neuronal deficiency of presenilin 1 Inhibits amyloid plaque formation and corrects hippocampal long-term potentiation but not a cognitive defect of amyloid precursor protein [V717I] transgenic mice. J Neurosci 22:3445-3453.

Dodart JC, Bales KR, Gannon KS, Greene SJ, DeMattos RB, Mathis C, DeLong CA, Wu S, Wu X, Holtzman DM, Paul SM (2002) Immunization reverses memory deficits without reducing brain $\mathrm{A} \beta$ burden in $\mathrm{Alz}$ heimer's disease model. Nat Neurosci 5:452-457.

Gellermann GP, Byrnes H, Striebinger A, Ullrich K, Mueller R, Hillen H, Barghorn S (2008) A $\beta$-globulomers are formed independently of the fibril pathway. Neurobiol Dis 30:212-220.

Hardy J, Selkoe DJ (2002) The amyloid hypothesis of Alzheimer's disease: progress and problems on the road to therapeutics. Science 297:353-356.

Hardy JA, Higgins GA (1992) Alzheimer's disease: the amyloid cascade hypothesis. Science 256:184-185.

Hartman RE, Izumi Y, Bales KR, Paul SM, Wozniak DF, Holtzman DM (2005) Treatment with an amyloid- $\beta$ antibody ameliorates plaque load, learning deficits, and hippocampal long-term potentiation in a mouse model of Alzheimer's disease. J Neurosci 25:6213-6220.

Holmes C, Boche D, Wilkinson D, Yadegarfar G, Hopkins V, Bayer A, Jones RW, Bullock R, Love S, Neal JW, Zotova E, Nicoll JA (2008) Long-term effects of A $\beta 42$ immunisation in Alzheimer's disease: follow-up of a randomised, placebo-controlled phase I trial. Lancet 372:216-223.

Katzman R, Terry R, DeTeresa R, Brown T, Davies P, Fuld P, Renbing X, Peck A (1988) Clinical, pathological, and neurochemical changes in dementia: a subgroup with preserved mental status and numerous neocortical plaques. Ann Neurol 23:138-144.

Kayed R, Head E, Thompson JL, McIntire TM, Milton SC, Cotman CW, Glabe CG (2003) Common structure of soluble amyloid oligomers implies common mechanism of pathogenesis. Science 300:486-489.

Kelly BL, Ferreira A (2006) $\beta$-amyloid-induced dynamin 1 degradation is mediated by $N$-methyl-D-aspartate receptors in hippocampal neurons. J Biol Chem 281:28079-28089.

Kelly BL, Vassar R, Ferreira A (2005) $\beta$-amyloid-induced dynamin 1 depletion in hippocampal neurons. A potential mechanism for early cognitive decline in Alzheimer's disease. J Biol Chem 280:31746-31753.

Koffie RM, Meyer-Luehmann M, Hashimoto T, Adams KW, Mielke ML, Garcia-Alloza M, Micheva KD, Smith SJ, Kim ML, Lee VM, Hyman BT, Spires-Jones TL (2009) Oligomeric amyloid $\beta$ associates with postsynaptic densities and correlates with excitatory synapse loss near senile plaques. Proc Natl Acad Sci U S A 106:4012-4017.

Lacor PN, Buniel MC, Chang L, Fernandez SJ, Gong Y, Viola KL, Lambert MP, Velasco PT, Bigio EH, Finch CE, Krafft GA, Klein WL (2004) Synaptic targeting by Alzheimer's-related amyloid $\beta$ oligomers. J Neurosci 24:10191-10200.

Lacor PN, Buniel MC, Furlow PW, Clemente AS, Velasco PT, Wood M, Viola KL, Klein WL (2007) A $\beta$ oligomer-induced aberrations in synapse composition, shape, and density provide a molecular basis for loss of connectivity in Alzheimer's disease. J Neurosci 27:796-807.

Lambert MP, Barlow AK, Chromy BA, Edwards C, Freed R, Liosatos M, Morgan TE, Rozovsky I, Trommer B, Viola KL, Wals P, Zhang C, Finch CE, Krafft GA, Klein WL (1998) Diffusible, nonfibrillar ligands derived from Abeta1-42 are potent central nervous system neurotoxins. Proc Natl Acad Sci U S A 95:6448-6453.

Lambert MP, Velasco PT, Chang L, Viola KL, Fernandez S, Lacor PN, Khuon D, Gong Y, Bigio EH, Shaw P, De Felice FG, Krafft GA, Klein WL (2007) Mononclonal antibodies that target pathological assemblies of A $\beta$. J Neurochem 100:23-35.

Lee EB, Leng LZ, Zhang B, Kwong L, Trojanowski JQ, Abel T, Lee VM (2006) Targeting amyloid- $\beta$ peptide $(\mathrm{A} \beta)$ oligomers by passive immunization with a conformation-selective monoclonal antibody improves learning and memory in $\mathrm{A} \beta$ precursor protein (APP) transgenic mice. J Biol Chem 281:4292-4299.

Lesné S, Koh MT, Kotilinek L, Kayed R, Glabe CG, Yang A, Gallagher M, Ashe $\mathrm{KH}$ (2006) A specific amyloid- $\beta$ protein assembly in the brain impairs memory. Nature 440:352-357.

Lue LF, Kuo YM, Roher AE, Brachova L, Shen Y, Sue L, Beach T, Kurth JH, Rydel RE, Rogers J (1999) Soluble amyloid $\beta$ peptide concentration as a predictor of synaptic change in Alzheimer disease. Am J Pathol 155:853-862. 
McLean CA, Cherny RA, Fraser FW, Fuller SJ, Smith MJ, Beyreuther K, Bush AI, Masters CL (1999) Soluble pool of A $\beta$ amyloid as a determinant of severity of neurodegeneration in Alzheimer disease. Ann Neurol $46: 860-866$.

Meyer-Luehmann M, Coomaraswamy J, Bolmont T, Kaeser S, Schaefer C, Kilger E, Neuenschwander A, Abramowski D, Frey P, Jaton AL, Vigouret JM, Paganetti P, Walsh DM, Mathews PM, Ghiso J, Staufenbiel M, Walker LC, Jucker M (2006) Exogenous induction of cerebral $\beta$-amyloidogenesis as governed by agent and host. Science 313:1781-1784.

Moechars D, Dewachter I, Lorent K, Reversé D, Baekelandt V, Naidu A, Tesseur I, Spittaels K, Haute CV, Checler F, Godaux E, Cordell B, Van Leuven F (1999) Early phenotypic changes in transgenic mice that overexpress different mutants of amyloid precursor protein in brain. J Biol Chem 274:6483-6492.

Nimmrich V, Grimm C, Draguhn A, Barghorn S, Lehmann A, Schoemaker H, Hillen H, Gross G, Ebert U, Bruehl C (2008) Amyloid $\beta$ oligomers (A $\beta_{1-42}$ globulomer) suppress spontaneous synaptic activity by inhibition of P/Q-type calcium channels. J Neurosci 28:788-797.

Pfeifer M, Boncristiano S, Bondolfi L, Stalder A, Deller T, Staufenbiel M, Mathews PM, Jucker M (2002) Cerebral hemorrhage after passive anti-A $\beta$ immunotherapy. Science 298:1379.

Racke MM, Boone LI, Hepburn DL, Parsadainian M, Bryan MT, Ness DK, Piroozi KS, Jordan WH, Brown DD, Hoffman WP, Holtzman DM, Bales KR, Gitter BD, May PC, Paul SM, DeMattos RB (2005) Exacerbation of cerebral amyloid angiopathy-associated microhemorrhage in amyloid precursor protein transgenic mice by immunotherapy is dependent on antibody recognition of deposited forms of amyloid $\beta$. J Neurosci 25:629-636.

Seubert P, Barbour R, Khan K, Motter R, Tang P, Kholodenko D, Kling K, Schenk D, Johnson-Wood K, Schroeter S, Gill D, Jacobsen JS, Pangalos M, Basi G, Games D (2008) Antibody capture of soluble $A \beta$ does not reduce cortical $\mathrm{A} \beta$ amyloidosis in the PDAPP Mouse. Neurodegener Dis 5:65-71.
Shankar GM, Bloodgood BL, Townsend M, Walsh DM, Selkoe DJ, Sabatini BL (2007) Natural oligomers of the Alzheimer amyloid-beta protein induce reversible synapse loss by modulating an NMDA-type glutamate receptor dependent signaling pathway. J Neurosci 27:2866-2875.

Shankar GM, Li S, Mehta TH, Garcia-Munoz A, Shepardson NE, Smith I, Brett FM, Farrell MA, Rowan MJ, Lemere CA, Regan CM, Walsh DM, Sabatini BL, Selkoe DJ (2008) Amyloid- $\beta$ protein dimers isolated directly from Alzheimer's brain impair synaptic plasticity and memory. Nat Med 14:837-842.

Teplow DB, Lazo ND, Bitan G, Bernstein S, Wyttenbach T, Bowers MT, Baumketner A, Shea JE, Urbanc B, Cruz L, Borreguero J, Stanley HE (2006) Elucidating amyloid $\beta$-protein folding and assembly: a multidisciplinary approach. Acc Chem Res 39:635-645.

Tokuda T, Calero M, Matsubara E, Vidal R, Kumar A, Permanne B, Zlokovic B, Smith JD, Ladu MJ, Rostagno A, Frangione B, Ghiso J (2000) Lipidation of apolipoprotein $\mathrm{E}$ influences its isoform-specific interactions with Alzheimer's amyloid beta peptides. Biochem J 348:359-365.

Walsh DM, Selkoe DJ (2007) A $\beta$ Oligomers: a decade of discovery. J Neurochem 101:1172-1184.

Walsh DM, Klyubin I, Fadeeva JV, Cullen WK, Anwyl R, Wolfe MS, Rowan MJ, Selkoe DJ (2002) Naturally secreted oligomers of amyloid $\beta$ protein potently inhibit hippocampal long-term potentiation in vivo. Nature 416:535-539.

Wang J, Dickson DW, Trojanowski JQ, Lee VM (1999) The levels of soluble versus insoluble brain $\mathrm{A} \beta$ distinguish Alzheimer's disease from normal and pathologic aging. Exp Neurol 158:328-337.

Yu L, Edalji R, Harlan JE, Holzman TF, Lopez AP, Labkovsky B, Hillen H, Barghorn S, Ebert U, Richardson PL, Miesbauer L, Solomon L, Bartley D, Walter K, Johnson RW, Hajduk PJ, Olejniczak ET (2009) Structural characterization of a soluble amyloid $\beta$-peptide oligomer. Biochemistry 48:1870-1877. 